\title{
THE BESIEGED: ROLE AND PLACE OF CIVILIAN POPULATION DURING A SIEGE AS PRESENTED IN MILITARY TREATISES OF LATE ANTIQUITY
}

\author{
Łukasz Różycki \\ Adam Mickiewicz University in Poznań
}

\begin{abstract}
The purpose of the article is to present the psychological aspects of defending a city in Late Antiquity, with particular focus on the role of civilians during a siege, according to the military treatises. The analysis covered mostly fragments of Book IV of Vegetius' work, Book X of Strategikon and passages from Syrianus Magister. The results clearly indicate that the authors of treatises knew well the significance of the soldiers' morale and mental strength in a siege, seeing them as key components in ensuring the success of military operations and preventing the surrender of the defended positions. The analyzed writings also emphasize the involvement of civilians, who were supposed to not only seek protection from soldiers, but actually had a clearly defined role in the defence efforts. The authors also understood that civilians, much more vulnerable to external stress factors than soldiers, were untrustworthy and more likely to give in to despair, which was to be prevented by various tricks meant to manipulate their psychology.
\end{abstract}

Key words: Roman Army, military psychology, sieges, Strategikon.

Słowa kluczowe: armia rzymska, psychologia pola walki, oblężenia, Strategikon.

The culminating point of many a conflict is not necessarily a pitched battle, but rather a siege, ${ }^{1}$ which can result in much heavier losses for the losing side than would have been suffered if a standing army was defeated in combat. In ancient Greece, capitulation of a city usually meant accepting defeat in war, ${ }^{2}$ and the safety of the walls

1 One of the most well-known and well-researched sieges from the Roman times was the taking of Masada: S.E.A. Wagner, Die Belagerung von Masada im Spiegel der menschlichen Überreste, Schild von Steier 27 (2015/2016), pp. 268-276.

2 It is difficult to imagine Athens or Sparta still waging war after the surrender of the polis itself. See more in: A. Chaniotis, Greeks under Siege: Challenges, Experiences and Emotions [in:] The Oxford Handbook of Warfare in the Classical World, ed. B. Campbell, L. Tritle, Oxford 2013, pp. 438-456.

Address for correspondence: lukasz.rozycki@amu.edu.pl 
of any polis was a priority matter, even during times of peace. ${ }^{3}$ This means that already in the Antiquity people put much thought into ways of defending the city walls, particularly if they were manned not by professional soldiers but by ordinary citizens answering the call to protect their home. The quality of the defending garrison was crucial; citizen-soldiers usually had good morale, but were not used to prolonged service and exposure to extreme stress factors. This could lead to the defenders breaking down under pressure from the enemy even if they had not yet been defeated in military terms. Various stratagems were employed to avoid such a situation. We know of whole schools of Greek tacticians, who have honed siege operations, both offensive as well as defensive, into a fine art. The first Greek military treatise was not created to impart knowledge about a regular battlefield, but rather as a collection of instructions on how to defend a besieged city. ${ }^{4}$ Many ages have passed between the times of Aeneas Tacticus and the Late Antiquity, and throughout that period the craft of staging and repelling a siege was being perfected. It was an arms race of sorts, between the besiegers and the besieged. If the attackers built a ramp, ${ }^{5}$ the defenders would at the same time build their walls up or excavate soil from under the face of the ramp so that it would collapse, thus thwarting the efforts of the attacking force. ${ }^{6}$ The situation was similar with regards to morale; the commander of the besieged city would use every trick at his disposal to maintain the spirits of his men, while the leader of the other side tried his best to force the defenders to surrender without resorting to a bloody assault. The defending force's duty was not only to repel the enemy from under the walls, but also to care for the safety of civilians, usually the city residents, but sometimes also the soldiers' own families taking shelter behind the walls of a border fortress. ${ }^{7}$ The threat to the civilian population was considerable. In Late Antiquity, Roman fortifications and cities were attacked by barbarians, who often dealt brutally with any civilians that resisted them (the most infamous in this regard were the nomads - the Huns and Avars). ${ }^{8}$

In order to explain the issue of retaliation against the civilians after capturing a given location, which is a recurring theme in historical sources, we need to take a look into the human psyche, namely the mechanisms related to being affected by extreme stressors for an extended period. ${ }^{9}$ An ongoing situation where one's life is in danger, like being under siege, has a negative impact on a person's mental condition;

3 See for example: Aeneas Tacticus, 3.5.

${ }^{4}$ La Guerre: trois tacticiens grecs: Énée, Asclépiodote, Onasandre, transl. by O. Battistini, Paris 1994.

See for example: H. Geva, The Siege Ramp Laid by the Romans to Conquer the Northern Palace at Masada, Eretz-Israel 25 (1996), pp. 297-306 (in Hebrew, with an English abstract).

6 A standout example of an ancient siege described in detail with a wide array of stratagems employed by both sides is the siege of Platea. Thucydides, 2.75-78 and 3.52.1-2.

7 Syrianus 9.30-33.

8 One example could be the Byzantine siege of Naples in 536, when Hun mercenaries after taking the city brutally turned on the civilian population.

9 The notion itself, and the scale, were introduced in the famous piece: T.H. Holmes, R.H. Rahe, The Social Readjustment Rating Scale, Journal of Psychosomatic Research 11 (1967), pp. 213-218. In modern times, similar studies of military personnel were carried out by a team of Hindu psychiatrists 
we must also take into account additional, even though less acute stressors, such as exhaustion, hunger, lack of sleep etc. Any man subjected to that many high stress factors accumulates negative emotions and sees the enemy as responsible for the situation that they're in. After a long-lasting siege the soldiers will obviously lash out against a city's defenders and take the opportunity to release some of the frustration and fear that they felt by turning on the civilian population. It is difficult to imagine an army disciplined enough not to behave this way. Frequently, the soldiers' frustration was further reinforced by desire (for riches, women, or alcohol), which only made them want to vent their emotions on the now-helpless enemies even more.

An assault on the city walls was a costly endeavor, ${ }^{10}$ especially for the attacking side, so it was usual for the besiegers to attempt to force the city into surrendering through a long-lasting blockade instead of direct assault. At times like these the mental pressure would affect not only the garrison of professional soldiers, but also the civilians, who were not used to living in such extreme conditions for long. History gives us numerous examples of the civilian population forcing the defenders to surrender. ${ }^{11}$

It is hard to understand the mindset of a soldier assaulting the high walls of a fortified position, braced for death. ${ }^{12}$ The effects of battlefield stress ${ }^{13}$ and frustration resulting from having to stay in one, exposed place, which was taxing both mentally and physically, meant that once the walls have been breached, the soldiers would naturally give in to their baser instincts, venting bottled up emotions on the defenders and civilians alike. Storming the walls of a hostile city was not only costly in terms of the lives of soldiers; if an assault was repelled it could deal a terrible blow to the attackers' morale, even forcing the army to lift the siege entirely. ${ }^{14}$ Consequently, the generals of Antiquity would only decide to launch a full-scale attack if they were convinced of its success; and even then they knew well to expect massive losses among their

and psychologists: S. Chaudhury, K. Srivastava, M.S.V. Kama Raju, S.K. Salujha, A Life Events Scale for Armed Forces Personnel, Indian Journal of Psychiatry 48/3 (2006), pp. 165-176.

10 D. Budacz, Drabiny jako urzadzenia oblężnicze w kontekście starożytnej techniki walki i morale żotnierzy, Prace Historyczne 141/4 (2014), pp. 809-818.

11 Sources from modern times confirm that city residents could exert pressure on garrison commanders. For example, the uprising of the residents of Gdańsk during the French siege of that city in 1807. E. Rozenkranz, Napoleońskie Wolne Miasto Gdańsk - ustrój, prawo, administracja, Gdańsk 1980, pp. 19.

12 One of the highest Roman military honors was the corona muralis, awarded to the soldier who first set foot on the walls of an enemy fortification. See more in: V.A. Maxfield, The Military Decorations of the Roman Army, London 1981.

${ }_{13}$ See the psychological basis for similar behaviors in pieces written for the use of the Polish Army: S. Konieczny, Panika wojenna, Warszawa 1969; idem, Strach i odwaga w dziataniach bojowych, Warszawa 1964; G. Nowacki, Organizacja i prowadzenie działan psychologicznych $w$ wybranych państwach, Torun 2004. An excellent breakdown of contemporary psychological warfare and its certain limitations can be found in: MC 402/1 NATO Military Policy on Psychological Operations. A history of discipline was presented by: C. Kennedy, E. Zillmer, Military Psychology Clinical and Operational Applications, New York 2006, pp. 1-21.

14 This was emphasized even by Vegetius, who pointed out that repelling the first assault is crucial for successful long-term defense. Veg. 4.12. 
men. Assaulting enemy defenses was seen as a necessary evil, and it was the commander's duty to achieve victory by any other means, preferably by forcing the other side to surrender. ${ }^{15}$ To that effect, the leaders relied on their intuitive insight into human psychology, making full use of the emotions that governed the behavior of the attacker and defender, aiming to spread fear among the enemy ranks and reinforce the confidence of their own troops. In this context, the attitude of the civilians was of crucial importance, often deciding the outcome of the siege. Consequently, any general would employ various tricks to achieve mental advantage over the defenders or improve the morale of the attackers.

Despite what might seem from the introduction, this piece will not be devoted to full-scale assaults or even sieges as a whole, but the means, or rather military stratagems that made it possible to take or hold a city with relatively less effort, by taking into account the civilians and their role. The analysis will focus on ways of improving the defenders' morale by using the civilian population. Employing ruses of war has always been the domain of civilized armies, and any leader who could secure victory without unnecessary bloodshed was a model to look up to. ${ }^{16}$ As far back as in the times of Aeneas Tacticus we've had armies use tricks that would give them advantage over their enemies or force the enemy to surrender based on false assumptions. A commander was supposed to shape the other side's perception of reality so that defending or attacking seemed too costly an undertaking. Today, at least to a certain extent, similar activities are referred to as psychological warfare, i.e. applying nonmilitary pressure on the enemy, but often by typically military means. In this piece I will analyze war stratagems used during sieges that relate to the civilian population.

In terms of methodology, we need to specify the chronological framework and the sources used in the study. The sources will be Roman-Byzantine military treatises, the work of Vegetius, ${ }^{17}$ the work written by Syrianus Magister during the reign of Emperor Justinian ${ }^{18}$ and the main source of analysis - the Strategikon, ${ }^{19}$ written at the end of the 6 th century by an experienced field commander. ${ }^{20}$ And so, in terms of

15 See for example: $Ł$. Różycki, Fear: An Aspect of Byzantine Psychological Warfare, Vox Patrum 35 (2015), vol. 63, pp. 459-473.

16 Strat. 8.1.7.

17 Flavii Vegeti Renati, Epitoma Rei Militaris, rec. C. Lang, Lipsiae 1869, hereinafter referred to as Veg. On the subject of dating of Vegetius' work see: M. Charles, Vegetius in Context Establishing the Date of the Epitoma Rei Militaris, Stuttgart 2007; T. Barnes, The Date of Vegetius, Phoenix 33/3 (1979), pp. 254-257.

${ }_{18}$ Further quoted as Syr. On the subject of dating see: P. Rance, The Date of the Military Compendium of Syrianus Magister (Formerly the Sixth-Century Anonymus Byzantinus), Byzantinische Zeitschrift 100/2 (2007), pp. 701-737.

19 Das Strategikon des Maurikios, ed. G.T. Dennis, transl. by E. Gamillscheg, Wien 1981. Hereinafter referred to as Strat.

20 Wiita suggested that the author of Strategikon was Philippicus. He was married to the sister of Emperor Maurice, Gordia; in the years 582-603 he served as comes excubitorum, and in the years 584$587 / 8$ as magister militum per orientem; he was also a successful field commander. Simocatta mentions that Philippicus was interested in the theory of strategy and the exploits of great leaders, with particular fondness for Scipio. The author of Strategikon had similar knowledge and was well-versed in theoretical works on warfare, sometimes mentioning famous commanders as examples of correct behavior on the 
chronology, I will cover a period between the treatise of Vegetius and the Strategikon, although some analogies will extend beyond that framework all the way to the time of Emperor Leo VI. For the purposes of this piece I will not be using the comparative method, i.e. deciding on the usefulness of suggestions given by Roman theoreticians based on narrative sources. All translations from Greek and Latin are my own. With regard to methodology, it should also be pointed out that this work is written in the spirit of new military history, ${ }^{21}$ employing the methods of study of social psychology and battlefield psychology; however, the basis for my approach will be the historical method, only supplemented with the aforementioned interdisciplinary elements.

\section{CIVILIANS DURING A SIEGE}

The non-combatants, who stayed within the walls usually became a serious burden in the event of a siege, and any discontent among them might lead to premature capitulation. It was the commander's duty to efficiently use the resources at his disposal during defense; this usually meant that those unfit for combat had to be evacuated. The author of Strategikon had the following to say on the matter:

You need to find out how much time the enemy intends to devote to the siege and, accordingly, think about the provisions that will be required. If there is too little, then even before the hostile force closes in, all those unable to fight - meaning the women, the elderly, the infirm and children - should be sent away from the fortifications, so that all available provisions are used solely by the fighting men. ${ }^{22}$

battlefield. Sym. I. 14.1-7. Moreover, the description of an ideal commander from Strategikon is very similar to the depiction of Philippicus in the work of Simocatta. These are, however, only clues, which do not solve the mystery of authorship, though they do expand the list of potential "candidates." J. Wiita, The Ethnika in Byzantine Military Treatises, University of Minnesota 1977, pp. 30-49.

${ }_{21}$ See the classic piece: C.A. du Picq, Études sur le combat, Paris 1880; and a study that is a seminal work for contemporary methodology of military history: J. Keegan, The Face of Battle, London 1976. Keegan's theses were implemented, among others, by: A.K. Goldsworthy, Armia rzymska na wojnie, transl., ed. Ł. Różycki, Oświęcim 2013. It’s also impossible not to mention a study for the US Army by S.L.A. Marshall, which was the first to emphasize the importance of psychology for military operations. S.L.A. Marshall, Men against Fire, New York 1947. In terms of methodology, it is worth mentioning a fundamental collection of works on deconstructing sources, which is a method often used by the new school of military history: H. Bloom, P. de Man, J. Derrida, G. Hartman, J.H. Miller, Deconstruction \& Criticism, New York 1979. Among Polish scholars, new methods of studying the social functions in the Roman army were successfully introduced by I. Łuć. See: I. Łuć, Boni et mali milites Romani. Relacje między żotnierzami wojsk rzymskich w okresie wczesnego cesarstwa, Kraków 2010. It would be valuable to compare these with pieces written with a more classic approach, see for example: R. MacMullen, The Legion as a Society, Historia: Zeitschrift für Alte Geschichte 22/4 (1984), pp. 440-56. Another important Polish piece is a volume of Prace Historyczne no. 141 (4) from 2014, entitled Stres pola bitwy od starożytności do dnia dzisiejszego, edited by M. S ta chura.

${ }_{22}$ X $\pi$ о

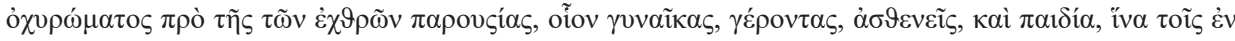


The author focuses on some key elements affecting the garrison's chances of withstanding a siege. One crucial factor is the amount of provisions that the defenders had secured behind the walls. ${ }^{23}$ This was even more important when a city was being blocked by barbarians with no sophisticated means of assaulting the fortifications, ${ }^{24}$ which was a common occurrence in Late Antiquity. ${ }^{25}$ The besieged force should have vast stores of food to be able to fight or wait out the siege for as long as possible. In order to limit food consumption, the author of Strategikon gives a very pragmatic advice to evacuate any civilians unable to participate in the fight. Since the provisions would then only be used by the soldiers, they would last for longer. We need to bear in mind that during a siege any non-combatants became a liability to the fighting men, exhausting the supplies and often exerting mental pressure on the defenders as a result of prolonged isolation and exposure to extreme stress factors.

During an enemy raid, those of the civilian population who lived outside the fortified area had to seek shelter by leaving their homes. ${ }^{26}$ The issue became a serious one, when these desperate people sought refuge behind the walls that were soon to be under siege. The author of Strategikon advised evacuating all civilians, both the refugees and the residents, but if that proved impossible, it was necessary to find a suitable place for the additional population. This problem was tackled in an interesting fashion by Syrianus Magister, who stated that the refugees should be given a place between the first and the second ring of fortifications. ${ }^{27}$ This was to prevent the city from becoming overcrowded and also to improve the fort's defensive capabilities.

An intriguing fact is that Romans saw two ways of using civilians to their benefit; in a treatise from the 10th century entitled Tactica,${ }^{28}$ we find the following passage:

If the siege is taking a long time, and you've managed to capture civilians outside the walls, retain the young, able-bodied men if you wish to do so, but send the women, children and the elderly back to the city. Thus, these useless people will further deplete the city's stores, without contributing anything in return. Moreover, they will cause all sorts of trouble for the defenders.

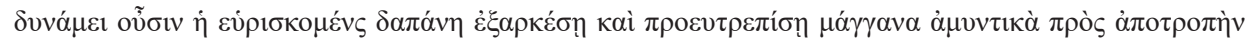
$\pi \varepsilon \tau \rho \circ \beta o ́ \lambda \omega v$. Strat. 10.3.5-13.

${ }_{23}$ As correctly pointed out by K. Dixon and P. Southern, we can distinguish between two kinds of sieges: blockades, intended to wear down the defenders and offensive sieges, which aim to take the fortifications by way of direct assault. Gathering supplies is one of the crucial elements when preparing to wait out a blockade. P. Southern, K. Dix on, The Late Roman Army, London 1996, pp. 150-152.

${ }_{24}$ Compare, for example, the methods of taking fortifications employed by the Avars. G. Kardaras, The Episode of Busas (596/7) and the Use of Siege Engines by the Avars, Byzantinoslavica 68 (2005), pp. 53-66.

25 L.I.R. Petersen, Siege Warfare and Military Organization in the Successor States (400-800 A.D.), Leiden 2013.

${ }^{26}$ To this effect the Romans built border refugia, where civilians could find shelter and safely store their possessions. Syrianus, 6.6-10.

27 Syrianus, 12.31-35.

28 The Taktika of Leon VI: Text, Translation, and Commentary, edited and transl. by G.T. Dennis, Washington 2010. 
You will also give those in the city a reason to expect humanitarian treatment. This should sow doubt in their minds and serve as the first step to making them submit to you. ${ }^{29}$

Both passages illustrate how civilians could be manipulated to achieve the biggest gains. The author of Strategikon suggested that civilians be removed from a besieged fortress in order to limit the consumption of supplies and thus ensure that the soldiers could defend longer. The same piece of advice, although subverted, was presented in Tactica written in the times of Leo the Philosopher. The treatise instructs how to ensure advantage by using enemy civilians. Sending women, children and the elderly away and into the besieged fortress was intended so that the defenders would run out of provisions quicker, ${ }^{30}$ but the psychological goal was equally important. Acting in this manner was to make the besieged population question their stubbornness, which would seem unnecessary if they saw that Romans could be merciful. The action was targeted specifically at civilians, through whom the author of Tactica wanted to influence the actual defenders. We should remember that in many cases the civilians left their whole life's fortune outside of the walls; and with the ongoing burden of the siege, the diminishing supplies, hunger, and disease, it's no wonder that they would have a negative attitude towards maintaining the defense. The stratagem was supposed to make people unwilling to resist, but also to show them an alternative solution, i.e. surrendering to the mercy of the Roman soldiers, who have already proven to be merciful. As a result, capitulation would seem a lesser evil, at least in the eyes of the besieged. The author of Strategikon echoes the advice given in Tactica in the part of his treatise devoted to maxims; he points out that civilians are the most likely to betray the defenders. Thus, the besieging force was instructed to send letters by employing deserters or by attaching them to arrows, in which Romans promised any traitors immunity and rewards. ${ }^{31}$

Another threat, which could also affect the civilians, was the loss of alertness. Vegetius gives an example of a stratagem that, in his opinion, was frequently used:

The attacking army will often turn to deceit; making it seem as if they've lost all hope of taking the city, lifted the siege and, arguably, left. Then, the fearful tension that gripped the defenders subsides, people cease their vigilance, guardsmen leave their posts and all turn their minds towards rest. But the enemies, having waited for precisely this moment, return in secret under cover of night and scale the walls on ladders. In order to protect against this ruse, whenever a hostile force retreats it is good to reinforce the guards on duty and erect huts for the lookouts on walls and towers, so that they are sheltered from rain and snowfall in winter, and from the sun during summer. ${ }^{32}$

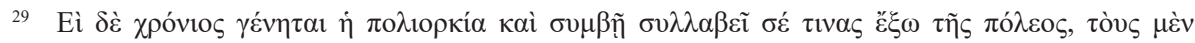

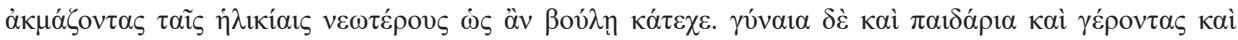

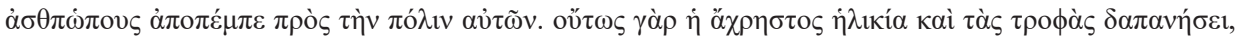

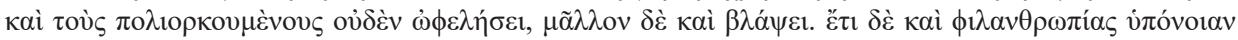

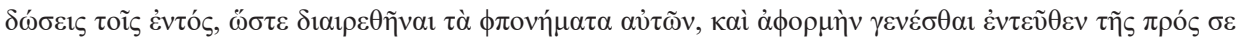

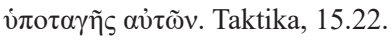

30 An equally important piece of advice was to not send away youths, who could strengthen the ranks of the defenders.

31 Strat. 8.1.21.

32 Veg. 4.26. 
This method for deceiving the defenders had been known throughout the ancient world already since the taking of Troy, and its effectiveness was based on the understanding of human psychology. After any period of increased tension, when one was under the influence of extreme stressors, the natural result is exhaustion. The human body, which up to that point had been mobilizing all its strength to deal with the stress factors, is simply spent and requires recovery, often leading to apathy. ${ }^{33}$ Once the enemy retreats, the defenders become more relaxed and less vigilant, which is then exploited by the returning attackers. Even if in this situation the soldiers manage to maintain discipline among the ranks, which is immensely difficult, ${ }^{34}$ any possible insubordination from the civilians might end in a disaster just as well.

If it was not possible to evacuate the civilian population, the defenders had to keep constant watch over them. Military stores were ever under threat of theft by desperate and hungry city residents, and misuse of water might cause its supply to run out:

If drinking water is supplied from wells or cisterns, access to these should be limited. No person can be allowed to use the water according to their whims. Sentries and their shifts must be planned for carefully, particularly during nighttime. Supplies should be restricted, and kept under guard, so that no passerby can easily steal them. ${ }^{35}$

Additionally, the author of Strategikon was aware of the problems that emerged when soldiers and civilians were forced to live together, confined within the walls under extreme conditions. It could lead to conflicts and pressures, which should be avoided at all cost:

The garrison troops should be positioned along the whole length of the walls. A suitable detachment should be dedicated as reserve to support the defenders on any section under too much pressure from the enemy. Thus, during combat, soldiers will not need to rush from their assigned positions to reinforce any struggling sections, which would leave other parts of the walls dangerously unprotected. If any civilians are left in the city, they need to join the soldiers at the walls and aid in the defense. As a result, they will be too preoccupied to conspire against the defenders; if civilians are assigned specific duties that support the defense efforts, they will be ashamed to even think of rebellion. ${ }^{36}$

33 A state of significantly decreased sensitivity to physical stimuli. See more in: B. Miedzińska, Podstawy psychologii, Jelenia Góra 2010, p. 66. This mechanism is well known to anyone who ever participated in a stressful event. Think about how your body reacts after an exceptionally difficult exam fatigue appears immediately once the stress factor is removed. Moreover, it is a natural instinct to unwind after being subjected to stress (at the end of every college exam session you can observe pubs filled with students looking for a way to release the tension).

34 Strat. 8B.11.1-15.

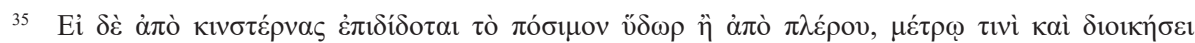

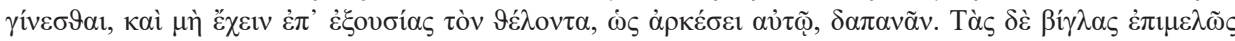

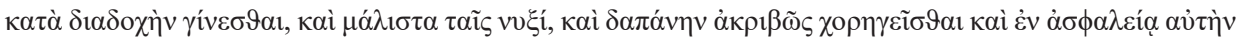

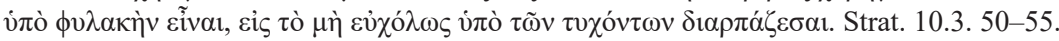

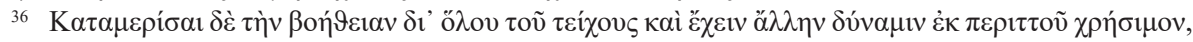

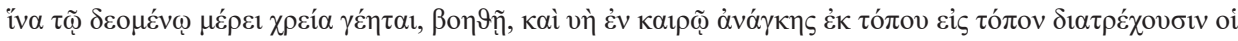

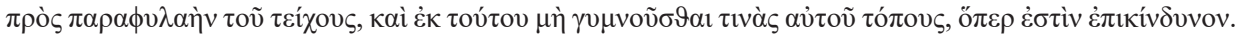

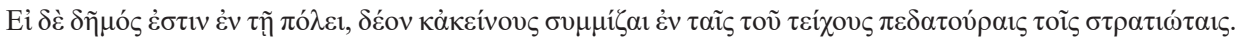


Apart from the fragment talking about the need for a reserve force during a siege, the author also touches upon a different, wildly interesting subject, namely that civilians left in the city should actively participate in the defense of their home. ${ }^{37}$ On the one hand, this increased the number of defenders, which surely boosted morale. On the other hand, the Strategikon clearly focuses on the psychological aspect of this course of action. Civilian residents involved by the commander in the war effort were supposedly less prone to rebellion and, implicitly, less likely to pressure the soldiers into surrendering. The author rightly observes that it is hard to start a rebellion when one is personally involved in the fighting; for one, because of lack of free time for scheming and conspiring; and two, because of shame. The latter reason is intriguing, and the author mentions it very deliberately, convinced that civilians participating in the defense would be ashamed to betray the soldiers, with whom they risked their lives. They could also feel embarrassed before their neighbors and other civilians, who also put their lives on the line during the siege and yet did not advocate mutiny or surrender. This indicates that the author of the treatise consciously manipulated the civilian population by suggesting they be involved in simple support tasks, which would provide more than simple military advantage.

In terms of typical military advantage, it could be gained by following Vegetius's suggestions regarding the civilians during a siege. The author of Epitoma Rei Militaris was no military commander himself, but he did make use of numerous ancient sources written by experienced practitioners or war. In his work he devotes relatively little space to civilian population, concentrating rather on the basics of defending the walls and on projectile siege engines. However, in his comments he also assigns a military role to the civilians living within the fortifications:

But there were also times when enemies, who had already got past the walls, were then cut
down to a man. History provides countless similar examples. Surely, it is only possible if the
garrison soldiers keep defending the walls, if the defenders occupy all the elevated positions in
the city and if the residents, regardless of age or gender, aid in the defense by dropping rocks
and all manner of other projectiles on the invaders. But if the civilians are unable to stand
against the enemy, the attackers usually break down the gates, so as to crush all resistance and
force the defenders to flee. In that pivotal moment, despair will lend strength to the besieged. If
the enemy has already breached the walls, then be it night or day, the only way for the residents
to survive is to man the walls and towers, take up elevated positions and defy the attackers on
every street and at every corner. ${ }^{38}$

The late ancient author clearly suggested using civilians to repel the enemy once the walls had been breached. Interestingly enough, Vegetius considered despair to be the main driving force for these defenders. This suggestion listed in Book IV

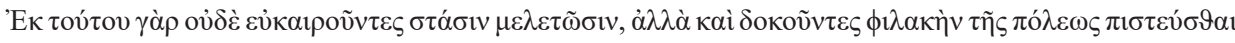

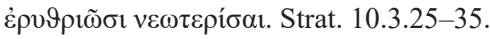

37 The issue of incorporating civilians in military operations was described more comprehensively in: C. Makrypoulias, Civilians as Combatants in Byzantium: Ideological versus Practical Considerations [in:] Byzantine War Ideology Between Roman Imperial Concept and Christian Religion, eds. J. Koder, I. Stouraitis, Vienna 2012, pp. 109-120.

38 Veg. 4.25.
} 
does not come from Vegetius' times, but from classical warfare, most probably that linked to Greek citizen-soldiers. The author himself confirms the ancient origins of this piece of advice when he refers to history in order to give credence to the idea. Most Late Roman authors did not consider this idea to be viable, seeing the unarmed masses rather as a hindrance to professional army operations than a last line of defense. Despite this, I believe Vegetius was correct. After a prolonged siege, knowing what cruel fate awaited them in the event of defeat, city residents could be expected to take up improvised weapons and offer fierce resistance. In such a hopeless situation men are usually governed by fear, and though their first instinct would be to run, there are examples when people driven into a corner decided to stand and fight. One of the people who learned the hard way the strength of a determined civilian defense was Pyrrhus - struck down by a projectile cast by a despairing mother from the roof of a residence. Other practitioners of war also knew about the danger of cornering an opponent, advising to always leave a way out for the enemy, even if it was only an illusion. ${ }^{39}$ Consequently, the defending mob would be overcome with fear, and despair would suppress the desire to fight for their lives, granting the attackers a swift victory.

The defense of city gates should be assigned to trusted individuals. Neither soldiers nor civilians may be allowed to make sorties against the enemy, especially at the beginning of the siege, even if our garrison is numerous and full of stout-hearted men. Engaging the enemy directly is only permissible when fighting off siege engines that cause significant damage to the walls. As a rule, soldiers should spend the siege on the walls, not risking their lives in direct clashes. If we allow for close combat to occur, our best and bravest men will either fall or end up wounded, and the rest of the force will lose heart, becoming easy prey for the enemy. Obviously, as long as we have sufficient numbers, the walls will be secure, but if one section is weakened, the whole defense will be threatened. If the fortifications include a curtain wall, it might be a good idea to place sentries there, especially at night, when someone might try to defect to the enemy side, or plan a treacherous stratagem against the defenders. Projectiles should only be cast from the walls when it is certain that they will be effective. ${ }^{40}$

This is yet another passage in Strategikon proving that during a siege morale was the key element. The quote can be divided into two parts. The first one talks about sorties, the second - about keeping the walls secure and dealing with deserters. Both bear closer examination. The author of the treatise expressly prohibited soldiers from leaving the safety of the walls. This was deemed unnecessary risky, even for a large,

39 Strat. 8.1.25.

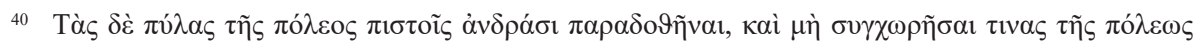

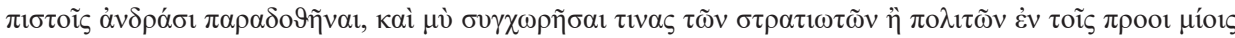

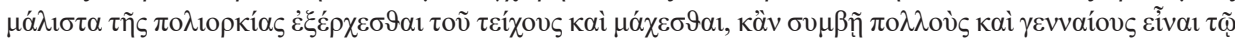

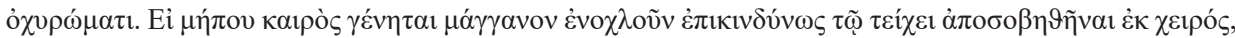

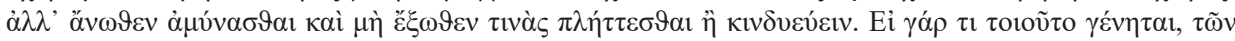

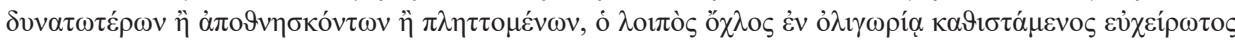

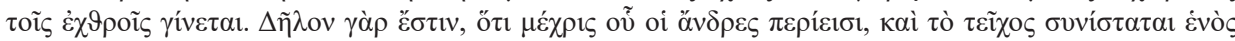

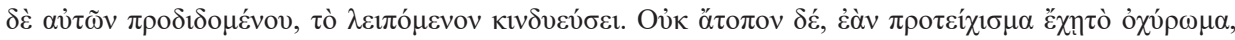

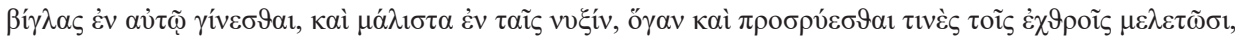

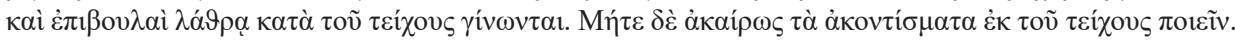
Strat. 10.3.35-50. 
well-equipped and disciplined garrison. Here once again we find mention of civilian residents of the besieged city - they were also forbidden to fight outside the walls. It is easy to understand the reasoning behind this approach. Raids on the enemy usually involved the bravest soldiers, while the rest of the defenders could only watch from the relative safety of the fortifications. If the Roman soldiers were to be defeated, morale would plummet - when the best and most experienced soldiers fall before the eyes of the whole army, the besieged undoubtedly start questioning their resolve and wondering what will happen to them, if even their champions ended up dead. The author of the treatise was keenly aware of this mechanism; moreover, he considered sorties to be a waste of effort, because normally the attackers were forced to storm the walls, which is always more difficult than engaging the defenders directly on the field. The loss of morale among the defenders could quickly result in surrender, even if the position was still defensible. ${ }^{41}$ Direct engagements were only allowed when dealing with siege engines. The besieged army had to make every effort to prevent them from reaching the walls. When faced with such a threat, a sortie was deemed an acceptable risk. ${ }^{42}$

It is also worth noting that the treatise suggests assigning trusted individuals to lead the defense of the gates. Gateways were a crucial section of fortifications, most likely to suffer the brunt of the assault, ${ }^{43}$ and losing them through treachery might lead to a swift defeat of the besieged force. Ancient Greeks firmly emphasized that defending the gates is one of the key tasks during a siege, and the person in charge of it should not only be a role model, but a paragon of morality as well, preferably someone whose family and property were hidden within the walls, as this would additionally ensure his loyalty. ${ }^{44}$

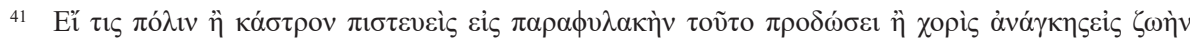

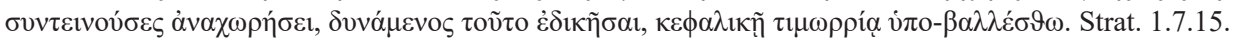

42 The author of the treatise described methods of defending against siege engines in great detail: "If they deploy siege towers, attack them with incendiary projectiles or stones. If that does not stop them, construct your own towers inside the walls directed against the enemy ones. It is crucial that wall towers, which are most vulnerable to enemy assault, should have no roofs. Thus, soldiers manning these towers will be able to fight unhindered; it will be easy to mount defensive siege weapons on these towers, and to operate them. Each tower should include a small, narrow gate, placed at an angle on the right hand side in the direction of enemy engines, so that our infantry can launch raids on the enemy being constantly protected by their own shields and soldiers stationed on the walls; this will force the enemy to withdraw his siege engines. These gates should also include a door, so that they can be secured when necessary

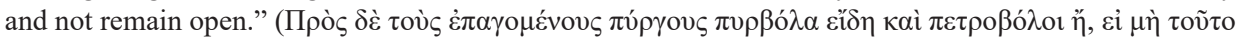

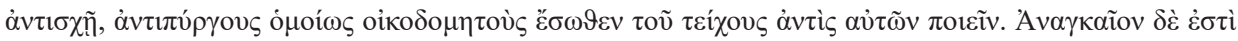

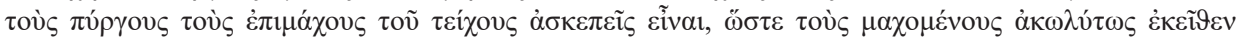

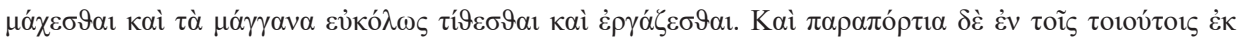

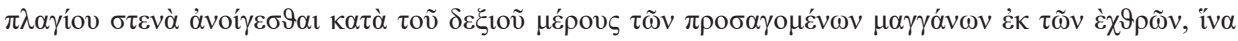

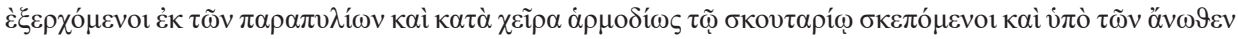

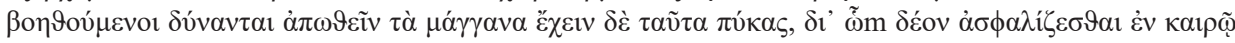

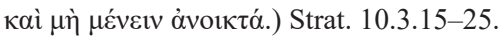

43 J. Prostko-Prostyński, Technika obrony bram w okresie rzymskim i wczesnobizantyjskim na przyktadzie fortyfikacji Mezji Dolnej i Pótnocnej Tracji, Balcanica Posnaniensia 1 (1984), pp. 265-270.

44 Aeneas Tacticus, V. 
The second part of the analyzed passage refers directly to battle fatigue. Being in a stressful situation for an extended period causes a person to start processing reality in an abnormal way; what is required and what is prohibited cease to be the deciding factors. A person subjected to unrelenting external stressors starts looking for a way out, even in a seemingly hopeless situation. ${ }^{45} \mathrm{~A}$ prolonged siege is a perfect example - people are trapped within the walls under constant threat of death. Something that every army since the Antiquity attempted to suppress through military training ${ }^{46}$ is that it is an instinctual human response to flee when facing danger. Flight, in turn, is inextricably linked to conformism - if one person runs away when their life is threatened, others will follow. ${ }^{47}$ The author of Strategikon knew that this could ensure the fall of any fortified position. A noteworthy idea is the role of the curtain wall in controlling the soldiers and civilians under one's command. The inner wall, which was stronger, served as the main defensive structure, but the outer wall was supposed to have sentries posted, especially at night, to protect against treachery. Soldiers stationed there were tasked with spotting deserters and defectors, who could attempt to sabotage the defense efforts from inside the walls.

\section{CONCLUSIONS}

The examples listed above illustrate that for late ancient authors the issues of morale and mental fortitude of soldiers during a siege were of key importance. It is also surprising to see so much attention devoted to civilians, especially in the case of Strategikon. Some stratagems originate from ancient times, as far back as from classical Greece, and some seem to be new methods devised in Late Antiquity. Each analyzed passage dealing with siege craft describes aspects of psychological warfare referred to deliberately by later authors, be they theoreticians or practitioners. This proves that both Greeks and Romans believed that the first and most important battle was the one that the soldier fought against himself, and it was the job of the commander to make every reasonable effort in order to prepare soldiers for the challenges

45 See: S. Konieczny, Panika wojenna ...; idem, Strach i odwaga...

46 Training in a modern army from a psychological point of view has been studied by: E. Hartmann, T. Sunde, W. Kristensen, M. Martinussen, Psychological Measures As Predictors of Military Training Performance, Journal of Personality Assessment 80/1 (2003), pp. 87-98. See also an excellent piece: H. Halff, J. Hollan, E. Hutchins, Cognitive Science and Military Training, American Psychologist 41 (1986), pp. 1131-1139. It is worth noting many similarities to the past and that currently employed methods of influencing soldiers are simply more evolved forms of the ones used in ancient times. Training in the Roman army was described in e.g.: S.E. Phang, Roman Military Service: Ideologies of Discipline in the Late Republic and Early Principate, Cambridge 2008, pp. 37-73. The issue of training was also touched upon in: R. MacMullen, op. cit., pp. 440-456.

47 The literature of the subject even includes the term "fear contagion" when describing a mob, in which individuals' awareness is suppressed: J. Pieter, Strach i odwaga, Warszawa 1971, pp. 112113; S. Baley, Wprowadzenie do psychologii spolecznej, Warszawa 1959, pp. 106-114. C.A. Kiesler, S.B. Kiesler, Conformity, Boston 1969. 
they would have to face. A noteworthy addition to these deliberations is the role of the civilian population and how civilians should be involved to fight for the Roman side. A soldier in a besieged city was subject to numerous stress factors, but thanks to his training was more resistant to these than anyone with no military experience. Civilians were faced with the same stressors and, worse still, had to bear in mind not only their own fate, but the fate of their families and possessions as well. This made people living within the fortifications more likely to be bribed by the attackers; they could open the gates for the enemies, pressure their own soldiers to stop fighting, and generally sabotage the defense. Late Roman authors were aware how civilians might pose a threat to the besieged force, and suggested very specific ways of preventing any issues from arising. All described methods of dealing with civilians are based on in-depth observations of human nature and make use of often atavistic mechanisms that govern our mentality. This means that even though Romans were not equipped with modern tools of social psychology, thanks to careful examination of human psyche they still intuitively made use of its findings.

\section{BIBLIOGRAPHY}

\section{Sources}

Aeneas Tacticus, Obrona oblężonego miasta, transl. by B. Burliga, Warszawa 2007.

The Anonymous Byzantine Treatise on Strategy [in:] Three Byzantine Military Treatises, ed., transl. by G.T. Dennis, Washington 1985.

Eneas el Táctico, Poliorcética. Polieno, Estratagemas, ed., transl. by V. Tejada, M. García, Madrid 1991.

Flavii Vegeti Renati, Epitoma rei militaris, rec. C. Lang, Lipsiae 1869.

La Guerre: trois tacticiens grecs: Énée, Asclépiodote, Onasandre, transl. by O. Battistini, Paris 1994.

Das Strategikon des Maurikios, ed. G.T. Dennis, transl. by E. Gamillscheg, Wien 1981.

The Taktika of Leon VI: Text, Translation, and Commentary, ed., transl. by G.T. Dennis, Washington 2010.

Theophylacti Simocattae Historiae, ed. C. de Boor, Lipsiae 1887.

Thucydides, Wojna peloponeska, thum. K. Kumaniecki, Warszawa 1988.

\section{Studies}

Baley S., Wprowadzenie do psychologii społecznej, Warszawa 1959.

Barnes T., The Date of Vegetius, Phoenix 33/3 (1979), pp. 254-257.

Bloom H., Man P. de, Derrida J., Hartman G., Miller J.H., Deconstruction \& Criticism, New York 1979. 
Budacz D., Drabiny jako urządzenia oblężnicze w kontekście starożytnej techniki walki i morale żotnierzy, Prace Historyczne 141/4 (2014), pp. 809-818.

Chaniotis A., Greeks under Siege: Challenges, Experiences and Emotions [in:] The Oxford Handbook of Warfare in the Classical World, ed. B. Campbe11, L. Tritle, Oxford 2013, pp. 438-456.

Charles M., Vegetius in Context Establishing the Date of the Epitoma Rei Militaris, Stuttgart 2007.

Chaudhury S., Srivastava K., Kama Raju M.S.V., Salujha S.K., A Life Events Scale for Armed Forces Personnel, Indian Journal of Psychiatry 48/3 (2006), pp. 165-176.

Geva H., The Siege Ramp Laid by the Romans to Conquer the Northern Palace at Masada, Eretz-Israel 25 (1996), pp. 297-306.

Goldsworthy A.K., Armia rzymska na wojnie, transl., ed. Ł. Różycki, Oświęcim 2013.

Halff H., Hollan J., Hutchins E., Cognitive Science and Military Training, American Psychologist 41 (1986), pp. 1131-1139.

Hartmann E., Sunde T., Kristensen W., Martinussen M., Psychological Measures as Predictors of Military Training Performance, Journal of Personality Assessment 80/1 (2003), pp. 87-98.

Holmes T.H., Rahe R.H., The Social Readjustment Rating Scale, Journal of Psychosomatic Research 11 (1967), pp. 213-218.

Kardaras G., The Episode of Busas (596/7) and the Use of Siege Engines by the Avars, Byzantinoslavica 68 (2005), pp. 53-66.

Keegan J., The Face of Battle, London 1976.

Kennedy C., Zillmer E., Military Psychology Clinical and Operational Applications, New York 2006, pp. 1-21.

Kiesler C.A., Kiesler S.B., Conformity, Boston 1969.

Konieczny S., Panika wojenna, Warszawa 1969.

Konieczny S., Strach i odwaga w działaniach bojowych, Warszawa 1964.

Łuć I., Boni et mali milites Romani. Relacje między żotnierzami wojsk rzymskich w okresie wczesnego cesarstwa, Kraków 2010.

MacMullen R., The Legion as a Society, Historia: Zeitschrift für Alte Geschichte 22/4 (1984), pp. 440-456.

Makrypoulias C., Civilians as Combatants in Byzantium: Ideological versus Practical Considerations [in:] Byzantine War Ideology Between Roman Imperial Concept and Christian Religion, eds. J. Koder, I. Stouraitis, Vienna 2012, pp. 109-120.

Marshall S.L.A., Men against Fire, New York 1947.

Maxfield V.A., The Military Decorations of the Roman Army, London 1981.

MC 402/1 NATO Military Policy on Psychological Operations.

Miedzińska B., Podstawy psychologii, Jelenia Góra 2010.

Nowacki G., Organizacja i prowadzenie działań psychologicznych $w$ wybranych państwach, Torun 2004.

Petersen L.I.R., Siege Warfare and Military Organization in the Successor States (400-800 A.D.), Leiden 2013.

Phang S. E., Roman Military Service: Ideologies of Discipline in the Late Republic and Early Principate, Cambridge 2008.

Picq C.A. du, Études sur le combat, Paris 1880.

Pieter J., Strach i odwaga, Warszawa 1971. 
Prostko-Prostyński J., Technika obrony bram w okresie rzymskim i wczesnobizantyjskim na przykładzie fortyfikacji Mezji Dolnej i Pólnocnej Tracji, Balcanica Posnaniensia 1 (1984), pp. 265-270.

Rance P., The Date of the Military Compendium of Syrianus Magister (Formerly the SixthCentury Anonymous Byzantinus), Byzantinische Zeitschrift 100/2 (2007), pp. 701-737.

Rozenkranz E., Napoleońskie Wolne Miasto Gdańsk - ustrój, prawo, administracja, Gdańsk 1980.

Różycki Ł., Fear an Aspect of Byzantine Psychological Warfare, Vox Patrum 35 (2015), t. 63 , pp. $459-473$.

Southern P., Dixon K., The Late Roman Army, London 1996, pp. 150-152.

Stres pola bitwy od starożytności do dnia dzisiejszego, ed. M. Stachura, Prace Historyczne 141/4 (2014).

Wagner S.E.A., Die Belagerung von Masada im Spiegel der menschlichen Überreste, Schild von Steier 27 (2015/2016), pp. 268-276.

Wiita J., The Ethnika in Byzantine Military Treatises, University of Minnesota 1977 [unpublished]. 